\title{
Intensive Care Cost Analysis of Patients with Acute Exacerbations of Chronic Obstructive Pulmonary Diseases from Two University Hospitals
}

\author{
Kronik Obstrüktif Akciğger Hastalı̆̆ı Akut Alevlenmesi Olan Hastalarm İki Üniversite Hastanesi \\ Yoğun Bakım Ünitesinde Tedavi Maliyetlerinin Hesaplanması
}

\author{
Mehmet Turan İNAL ${ }^{1}$, Dilek MEMIŞ่ ${ }^{1}$, Birgül Büyükkıran YELKEN $^{2}$, Necdet SÜT ${ }^{3}$ \\ ${ }^{1}$ Trakya Üniversitesi Trp Fakültesi, Anesteziyoloji ve Reanimasyon Anabilim Dal, Edirne \\ ${ }^{2}$ Osmangazi Üniversitesi Tıp Fakültesi, Anesteziyoloji ve Reanimasyon Anabilim Dalı, Eskişehir \\ ${ }^{3}$ Trakya Üniversitesi Tip Fakültesi, Biyoistatistik Anabilim Dal, Edirne
}

Submitted / Başvuru tarihi: 16.02.2009 Accepted / Kabul tarihi: 05.06.2009

\begin{abstract}
Objective: Chronic Obstructive Pulmonary Disease (COPD) is a leading cause of death worldwide with a continued rising mortality rate, and it represents a major socioeconomic burden. The aim of this study was to examine the costs of acute exacerbation of COPD patients admitted to two different university hospital intensive care units.
\end{abstract}

Material and Methods: We analyzed 156 patients (128 male and 28 female) who were admitted for treatment of acute exacerbations of COPD from January 1, 2005 to June 15, 2008.

Results: The mean age of the patients was 68.2 years. The mean length of hospitalisation stay was 10.4 days. The costs were different between survivors and nonsurvivors. There was a statistically significant difference between survivors and non-survivors groups in all costs except bed costs, laboratory costs, radiology costs and consultation costs.

Conclusion: These results suggest that the cost of patients with acute exacerbations of COPD represents a considerable economic burden for the health care system in Turkey.

Key words: Chronic obstructive pulmonary disease; acute exacerbation; cost analysis.
Amaç: Kronik obstrüktif akciğer hastalığı (KOAH) dünya çapında ölümlerin ana nedeni olup, mortalite hızı sürekli yükselmekte ve önemli sosyoekonomik yük oluşturmaktadır. Bu çalışmada iki farklı üniversite hastanesi yoğun bakım ünitesinde $\mathrm{KOAH}$ akut alevlenmesi olan hastaların maliyetlerinin incelenmesi hedeflenmiştir.

Gereç ve Yöntemler: 1 Ocak 2005 ile 15 Haziran 2008 tarihleri arasında $\mathrm{KOAH}$ akut alevlenmesi nedeniyle tedavi olan 156 hasta (128 erkek ve 28 kadın) analiz edilmiştir.

Bulgular: Hastaların ortalama yaşı 68.2 olarak bulunmuştur. Ortalama hastanede kalış süresi 10.4 gün olarak saptanmıştır. Sağ kalan ve ölen hastaların maliyetleri birbirlerinden farklı bulunmuştur. Sağ kalanlar ve ölen hastalar arasında yatak ücreti, laboratuar ücreti, radyoloji ücreti ve konsültasyon ücretleri dışındaki diğer tüm tedavi maliyetlerinde istatistiksel farklılık saptanmışıı.

Sonuç: $\mathrm{KOAH}$ akut alevlenmesi olan hastaların tedavi maliyetlerinin Türk sağlık sistemi içinde hatırı sayılır yer oluşturduğunu düşünmekteyiz.

Anahtar sözcükler: Kronik obstrüktif akciğer hastalı̆ı; akut alevlenme; maliyet analizleri.

Correspondence (illetişim adresi): Dr. Mehmet Turan İnal. Trakya Üniversitesi Tıp Fakültesi, Anesteziyoloji ve Reanimasyon Anabilim Dalı, Edirne, Turkey. Tel: 02842357857 e-mail (e-posta): mehmetturaninal@yahoo.com

๑ Trakya Üniversitesi Tıp Fakültesi Dergisi. AVES Yayıncıllık tarafından basılmıştır. Her hakkı sakıdır.

(๑) Medical Journal of Trakya University. Published by AVES Publishing. All rights reserved. 


\section{INTRODUCTION}

Chronic Obstructive Pulmonary Disease (COPD) is characterized by progressive airway obstruction which is not completely reversible with bronchodilatator medications. $^{[1]}$ Exacerbation symptoms include increased dyspnea, cough and sputum, as well as changes in sputum colour. Exacerbations are associated with a significant worsening of pulmonary function and are considered to be the cause of an increase in the costs of COPD treatment. ${ }^{[2,3]}$

COPD is a leading cause of death worldwide, with a continued rising mortality rate and it represents a major socioeconomic burden. According to World Health Organization (WHO) estamates, 80 million people have moderate to severe COPD and three million people died of COPD in 2005..$^{[4]}$ Acute respiratory failure is a common and often fatal complication of COPD, requiring mechanical ventilation. ${ }^{[5]}$ The burden of COPD extends beyond the patient to the health care system and society as a whole.

Intensive care units (ICUs) are important departments for hospitalized patients with acute exacerbations of COPD and represents the largest clinical cost centers in hospitals in other parts of the world..$^{[6,7]}$ Even though cost studies have been conducted in some countries, ${ }^{[8-15]}$ the detailed cost of acute exacerbations of COPD in ICU in Turkey has not been studied.

The aim of this study was to identify the detailed cost of treatment of acute exacerbations of COPD in two different university hospital intensive care units.

\section{MATERIALS AND METHODS}

This study was a retrospective review of all ICU records from January 1, 2005 and June 30, 2008. During this period, 1221 patients were admitted to the adult medical and surgical ICU. Of these, there were 156 patients with acute exacerbations of COPD, which made up the study population.

Acute exacerbation of COPD was diagnosed with increased dyspnea, sputum production or purulence without radiographic evidence of consolidation. Exclusion criteria included pneumonia, asthma, pulmonary tuberculosis, bronchiestasis, pulmonary fibrosis and lung cancer.

The hospitalisation costs in this analysis were identified for bed costs, laboratory costs (blood, urine and other specimens detection costs), therapy costs (invasive mechanical ventilation and hemodialysis costs), drug costs, radiology costs (chest $\mathrm{X}$ ray, $\mathrm{CT}$ costs), transfusion costs, medical equipment costs (central venous cathater, perfusion sets costs) and consultation costs.

Information about age, gender, length of stay and outcome (alive or death) was collected from the ICU records. The patients were categorized by the outcome.
The study protocol was approved by the local ethics committee.

\section{Cost Assessment}

A computerized hospital accounting software and patient records of the ICU were used for calculation of the costs. All costs were expressed as US dollars using the mean annual purchasing power parity values of Turkey in 2005, 2006, 2007 and 2008 years ( 1 US $\$=1.35$, $1.56,1.32$ and 1.20 , respectively). ${ }^{[16]}$

\section{StatisticalAnalysis}

The numeric results were expressed as mean \pm sd, and categorical results were expressed as a number. Normality distribution of the variables was tested using one sample Kolmogorov Smirnov test. Differences between groups were assessed using the students' $t$ test for normal, the Mann Whitney $U$ test for non-normal distributed data. The chi-square test was used to compare the differences of categorical variables between the groups. A P-value $<0.05$ was considered as statistically significant. Statistica 7.0 (StatSoft Inc. Tulsa, OK, USA) statistical software was used for statistical analyses.

\section{RESULTS}

Between January 1, 2005 and June 30, 2008, 1221 patients were admitted to the ICUs and of these 156 patients with exacerbation of COPD. In the event that a patient presented to the ICU on more than one occasion, only one data from the first hospital admisson was analysed.

A total of 156 patients were enrolled in the study, 128 of them were men, 28 were women. The mean age of the patients was $68.2 \pm 10.23$ years. The mean length of ICU stay was $10.4 \pm 12.57$ days. Gender, age and length of ICU stay of patients are shown in Table 1 . There was no statistically difference in age and gender $(p>0.05)$ between survivors and non-survivors. Length of ICU stay was statistically different between groups $(\mathrm{p}<0.005)$.

A total of 156 patients had respiratory failure. The comorbid diseases of the patients were as follows; cerebral vascular disease, renal failure, coronary heart disease and hypertension. Comorbid diseases were higher in the non-survivor group. In the survivor group 22 patients had comorbid diseases compared to 60 patients in the non-

Table 1. General characteristics of admitted patients with acute exacerbations of COPD

\begin{tabular}{lccc}
\hline & $\begin{array}{c}\text { Survivors } \\
(\mathrm{n}=89)\end{array}$ & $\begin{array}{c}\text { Non-survivors } \\
(\mathrm{n}=67)\end{array}$ & $\mathrm{p}$ \\
\hline Sex (M/F) & $73 / 16$ & $55 / 12$ & 0.991 \\
Age (years) & $66.87 \pm 10.40$ & $70.05 \pm 9.80$ & 0.058 \\
Length of ICU stay (days) & $8.58 \pm 13.38$ & $12.89 \pm 11.04$ & $0.001^{*}$ \\
\hline
\end{tabular}

Data are presented as range (mean $\pm \mathrm{SD})$ median unless otherwise indicated.

ICU; Intensive care unit

*Difference between both groups. 
survivor group. The length of hospital stay was longer in patients with comorbid disease. Length of stay was $8.09 \pm 14.04$ days in patients without comorbid diseases and $12.54 \pm 10.74$ days in patients with comorbid diseases. The difference was statistically different $(p<0.01)$.

The costs were different between survivor and nonsurvivor groups. There was a statistically significant difference in drug costs, medical equipment costs, therapy costs and transfusion costs between survivor and nonsurvivor groups $(\mathrm{p}<0.01)$. Between survivor and nonsurvivor groups, there were no statistically difference in bed costs, laboratory costs, radiology costs and consultation costs $(p>0.05)$. Total ICU costs were higher in the non-survivor group than the survivor group $(\mathrm{p}<0.05)$. The detailed information of the intensive care cost composition was given in Table 2.

\section{DISCUSSION}

In this retrospective study, the aim was to investigate the hospitalization cost of patients with acute exacerbation of COPD in intensive care units in two university hospital in Turkey. These results suggest that there was a statistically significant difference in drug costs, medical equipment costs, therapy costs and transfusion costs between survivor and non-survivor groups.

General characteristics of patients with acute exacerbations of COPD in ICU are demonstrated by several studies. ${ }^{[8-15]}$ Añón et al. ${ }^{[8]}$ analysed the prognosis and costs of mechanical ventilation in patients with exacerbations of COPD in an university hospital ICU. They found that the mean age was 64 years (44-77). They did not demonstrate a statistically significant difference among ages of survivals and non-survivals. The mean length of stay in the ICU was 41 days and mortality rate was $35 \%$ in the ICU, like this study. Ely et al. ${ }^{[9]}$ made

Table 2. Hospitalization cost composition in patients with acute exacerbations of COPD

\begin{tabular}{lccc}
\hline Costs & $\begin{array}{c}\text { Survivors } \\
(\mathrm{n}=89)\end{array}$ & $\begin{array}{c}\text { Non-survivors } \\
(\mathrm{n}=67)\end{array}$ & $\mathrm{p}$ \\
\hline Bed cost & $227.85 \pm 237.79$ & $314.72 \pm 323.76$ & 0.207 \\
Drug cost & $602.72 \pm 644.72$ & $810.48 \pm 726.38$ & $0.034^{*}$ \\
Medical equipment & $599.078 \pm 2130.71$ & $591.49 \pm 564.84$ & $0.012^{*}$ \\
costs & & & \\
Laboratory cost & $565.61 \pm 365.05$ & $593.95 \pm 355.36$ & 0.365 \\
Therapy cost & $261.06 \pm 252.19$ & $418.38 \pm 400.88$ & $0.022^{*}$ \\
Transfusion cost & $207.96 \pm 479.82$ & $425.31 \pm 654.79$ & $0.001^{*}$ \\
Radiology cost & $26.47 \pm 26.56$ & $36.75 \pm 46.50$ & 0.463 \\
Consultation cost & $0.63 \pm 1.7$ & $1.30 \pm 3.38$ & 0.320 \\
Total cost & $2491.40 \pm 2671.48$ & $3192.41 \pm 2416.19$ & $0.018^{*}$ \\
\hline
\end{tabular}

Data are presented as range (mean \pm SD) median unless otherwise indicated.

*Difference between both groups. a study to delineate the costs of care of patients with COPD and found that the mean age was 65 years. The mean length of stay in the ICU was 9 days and mortality rate was $38.6 \%$. Chen et al. ${ }^{[10]}$ made a study to determine the costs of acute exacerbations of COPD. They concluded that the mean age was 73.4 years and the mean length of stay in the ICU was 20.7 days. Berkius et al. ${ }^{[11]}$ made an analysis of cases of acute exacerbations in COPD and demonstrated that the mean age was 70.2 years and mortality was $7.3 \%$. Ai-Ping et al. ${ }^{[12]}$ concluded that the mean age was 70 years, mortality was $10.5 \%$ and the mean ICU stay was 3 days. 60 patients were admitted to this study and $95 \%$ of patients received invasive mechanical ventilation. The mean age for survivors was 68.1 and 75.8 years for non-survivors. Another study from Italy by Iapichino et al. ${ }^{[13]}$ concluded that the mean ICU stay was 10.5 days and mortality rate was $71.25 \%$. Bertolini et al. ${ }^{[14]}$ analysed the cost of COPD and found that the mean age was 71.3 years and mortality rate was $16.9 \%$. In this study the mean ICU stay was 7 and 9 days for survival and non-survival groups respectively. Rossi et al. ${ }^{[15]}$ analysed the costs of 1034 patients in 51 ICUs. The mortality rate was $22.8 \%$.

In our study, the mean age of the patients was 68.2 years. Similar to the Ai-Ping study, the mean age for survivors was 66.8 and 70 years for non-survivors. We did not demonstrate a statistically significant difference among ages of survivals and non-survivals. The mean lenght of stay in the ICU was different in survivors and non-survivor groups. In survivors group the mean lenght of stay was 8,58 days, in non-survivors this was 12.89 days. There was statistically significant difference $(p<0.05)$. We found that the mortality rate was $42.9 \%$, this result was higher than previous studies, ${ }^{[8,9,11,12,14,15]}$ but in our study all of the patients had respiratory failure and had mechanical ventilation.

Añón et al. ${ }^{[8]}$ found that comorbid diseases were presented in 8 patients of 20 patients. Chen et al. ${ }^{[10]}$ demonstrated that 204 of 439 patients had respiratory failure, 153 had cor pulmonale, 123 had coronary artery disease, 231 had hypertension, 70 had cerebrovascular disease and 32 had renal failure. Ai-Ping et al. ${ }^{[12]}$ concluded that $55 \%$ of patients had two or more comorbid conditions. In our study we demonstrated that a total of 82 patients had comorbid diseases like cerebral vascular disease, renal failure, coronary heart disease and hypertension. In the survivor group, 22 patients had comorbid disease compared to 60 patients in the non-survivor group.

Several previous studies demonstrated the costs of patients with acute exacerbations of COPD. ${ }^{[8-10,13-15]}$

Añón et al. ${ }^{[8]}$ evaluated 206 admissions due to COPD, 20 patients met the inclusion criteria of their study and demonstrated that the total cost in the ICU was U.S. $\$ 1359061$, with a mean cost per patient of U.S. $\$ 67953$. They did not demonstrate the composition of intensive care costs. Chen et al. ${ }^{[10]}$ investigated hospitalization cost composition of different hospitals and reported that the highest absolute cost was drug cost, followed 
by laboratory cost, oxygen cost, therapy cost, radiology cost, examination cost and bed costs. They found that the percentage of drug cost was $71.2 \%$. They concluded that there was a significant statistical difference in all costs except for company cost, oxygen cost and transfusion cost among different centers. Ely et al. ${ }^{[9]}$ investigated the hospitalization cost composition of patients with COPD patients and other mechanically ventilated patients. They concluded that the highest cost was bed expenses, followed by drug costs, respiratory care costs, mechanical ventilation costs, radiology costs and laboratory costs. The percentage of bed cost was $27.14 \%$ and drug cost was $25.2 \%$. Iapichino et al. (13) found that the mean cost per patient was $€ 1648.9$ in survivor groups and $€ 2466.7$ in non-survivor group. Bertolini et al. ${ }^{[14]}$ compared the costs and found that the highest cost was laboratory costs, followed by drug cost and procedures cost in the survivor group. In the non-survivor group laboratory cost was the highest cost, followed by procedures cost and drug cost. Total cost per patient was $€ 1316.5$ for the survivor group and $€ 2662$ for non-survivors. The authors concluded that there was a statistically significant difference in total costs per patient between survivor and non-survivor groups. Rossi et al. ${ }^{[15]}$ found that total cost per patient was $€ 1979$. The highest cost was laboratory costs, followed by consumables cost and drug cost.

In our study, we demonstrated the hospitalization costs in ICU from two university research hospital and categorized by the outcome. We concluded that the highest absolute cost was drug cost $(24.19 \%)$, followed by medical equipment cost, laboratory cost, therapy cost, bed cost, transfusion cost, radiology cost and consultation costs in survivors. In non-survivors the highest cost was drug cost (25.3\%) followed by laboratory cost, medical equipment costs, transfusion cost, therapy cost, bed cost, radiology cost and consultation costs. There was a statistically significant difference in all costs except bed cost, laboratory cost, radiology cost and consultation costs between survivors and non-survivors. Total intensive care costs with a mean cost per patient of $\$ 2491,40$ in survivors and $\$ 3192,41$ in non-survivors . Comparison of our results with the cost studies ${ }^{[8-10,13-15]}$ can give some idea but would be of limited value, because of the differences in the health care system and study design.

Chen et al. ${ }^{[10]}$ concluded that the total hospitalization cost was positively correlated with length of hospital stay, age and comorbid diseases. Another study made by Ely et al. ${ }^{[9]}$ found no correlation between age and total hospitalization costs. In our study we found that the length of hospital stay was longer in patients with comorbid disease, but we did not find any statistically significant difference between patients with comorbid diseases and mean ICU cost per day $(\mathrm{p}=0156)$.

In conclusion, intensive care costs of COPD causes a considerable economic burden for the health care system in Turkey. This study provides detailed information on costs and it may be representative of intensive care costs of COPD for developing countries.

\section{Conflict of Interest}

No conflict of interest declared by the authors.

\section{REFERENCES}

1. O'Donnell DE, Hernandez P, Aaron S, Bourbeau J, Marciniuk $\mathrm{D}$, Hodder $\mathrm{R}$, et al. Canadian thoracic society COPD guidelines: summary of highlights for family doctors. Can Respir J 2003;10:183-5.

2. Donaldson GC, Seemungal TA, Bhowmik A, Wedzicha JA. Relationship between exacerbation frequency and lung function decline in chronic obstructive pulmonary disease. Thorax 2002;57:847-52.

3. Hilleman DE, Dewan N, Malesker M, Friedman M. Pharmacoeconomic evaluation of COPD. Chest. 2000;118:1278-85.

4. World Health Organisation, chronic respiratory diseases. http://www.who.int/respiratory/copd/en/ Ref type: Electronic station

5. Hurd S. The impact of COPD on lung health worldwide: epidemiology and incidence. Chest. 2000 Feb;117:1S-4S.

6. Parviainen I, Herranen A, Holm A, Uusaro A, Ruokonen E. Results and costs of intensive care in a tertiary university hospital from 1996-2000. Acta Anaesthesiol Scand. 2004;48:55-60.

7. Noseworthy TW, Konopad E, Shustack A, Johnston R, Grace M. Cost accounting of adult intensive care: methods and human and capital inputs Crit Care Med. 1996;24:1168-72.

8. Añón JM, García de Lorenzo A, Zarazaga A, Gómez-Tello V, Garrido G. Mechanical ventilation of patients on longterm oxygen therapy with acute exacerbations of chronic obstructive pulmonary disease: prognosis and cost-utility analysis. Intensive Care Med. 1999;25:452-7.

9. Ely EW, Baker AM, Evans GW, Haponik EF. The distribution of costs of care in mechanically ventilated patients with chronic obstructive pulmonary disease. Crit Care Med. 2000;28:408-13.

10. Chen $Y H$, Yao WZ, Cai BQ, Wang H, Deng XM, Gao HL, et al. Economic analysis in admitted patients with acute exacerbation of chronic obstructive pulmonary disease. Chin Med J (Engl). 2008;121:587-91.

11. Berkius J, Nolin T, Mårdh C, Karlström G, Walther SM. Characteristics and long-term outcome of acute exacerbations in chronic obstructive pulmonary disease: an analysis of cases in the Swedish Intensive Care Registry during 2002-2006. Acta Anaesthesiol Scand. 2008;52:759-65.

12. Ai-Ping C, Lee KH, Lim TK. In-hospital and 5-year mortality of patients treated in the ICU for acute exacerbation of COPD: a retrospective study. Chest. 2005;128:518-24.

13. Iapichino G, Radrizzani D, Simini B, Rossi C, Albicini M, Ferla L, et al. Effectiveness and efficiency of intensive care medicine: variable costs in different diagnosis groups Acta Anaesthesiol Scand. 2004;48:820-6.

14. Bertolini G, Confalonieri M, Rossi C, Rossi G, Simini B, Gorini M, et al. GiViTI (Gruppo italiano per la Valutazione degli interventi in Terapia Intensiva) Group; Aipo (Associazione Italiana Pneumologi Ospedalieri) Group. Costs of the COPD. Differences between intensive care unit and respiratory intermediate care unit. Respir Med. 2005;99:894-900.

15. Rossi C, Simini B, Brazzi L, Rossi G, Radrizzani D, Iapichino $\mathrm{G}$, et al. Variable costs of ICU patients: a multicenter prospective study. Intensive Care Med. 2006;32:545-52.

16. Central Bank of The Republic of Turkey Exchange Rates. Assessed on September 15, 2008, at. 